\title{
AJANKOHTAISTA
}

\section{Uutta tutkimustietoa iäkkäiden sosiaalisesta hyvinvoinnista - SoWell-tutkimushankkeen laaja kyselyaineisto on valmistunut}

Vanheneminen ja sosiaalinen hyvinvointi (SoWell) on tutkimushanke, jonka tavoitteena on tuottaa tietoa iäkkäiden ihmisten sosiaalisesta hyvinvoinnista sekä keinoista, joilla sosiaaliseen hyvinvointiin voidaan vaikuttaa (Pirhonen ym.2018; Ahosola ym.2021). SoWell on Tampereen yliopistossa Gerontologian tutkimuskeskuksen (GEREC) ja Ikääntymisen ja hoivan tutkimuksen huippuyksikön ( $\mathrm{CoE}$ AgeCare) yhteydessä toteutettava tutkimuskokonaisuus (https://projects.tuni.fi/sowell/). Tutkimusta on rahoittanut vuodesta 2018 lähtien Päivikki ja Sakari Sohlbergin säätiö. Iäkkäiden ihmisten sosiaalinen hyvinvointi ja osallisuus yhteiskunnassa ovat viime vuosina nousseet tärkeiksi keskustelun ja tutkimuksen aiheiksi. SoWell-hankkeessa lähdemme ajatuksesta, että yleiset sosiaalisen hyvinvoinnin määritelmät eivät välttämättä kerro koko totuutta ikääntyneiden ihmisten sosiaalisesta hyvinvoinnista tai siitä, miten vanheneminen muuttaa sosiaalisen hyvinvoinnin painotuksia. Hankkeen keskeinen tavoite onkin selvittää, mitä tekijöitä ikääntyvät ihmiset itse pitävät hyvinvoinnilleen tärkeinä ja miten eri hyvinvoinnin osa-alueet ovat yhteydessä toisiinsa.

SoWell-hankkeessa on koottu kolme itsenäistä, toisiaan täydentävää tutkimusaineistoa: 1) vuosina 2018-2019 tehdyt ryhmäkeskustelut ja yksilöhaastattelut, 2) kesällä 2020 toteutetut puhelinhaastattelut, joissa pääteemana oli iäkkäiden ihmisten selviytyminen korona-ajan arjesta sekä 3) postikysely, jonka aineiston keruu päättyi keväällä 2021 ja johon tässä kirjoituksessa keskitymme. Talvella 2020-2021 toteutetun postikyselyn tavoitteena oli selvittää, missä määrin aiemmassa tutkimuskirjallisuudessa ja tämän tutkimuksen aikaisemmissa vaiheissa (ryhmäkeskustelut ja yksilöhaastattelut) esiin tulleet sosiaalisen hyvinvoinnin elementit ja niiden parantamiseksi esitetyt toimet ovat yleistettävissä yli 65-vuotiaisiin suomalaisiin. Samalla tavoitteena oli saada koko maata edustavaa tietoa hyvinvoinnin keskeisistä tekijöistä sekä alueellisista ja sosiaalisen taustan mukaisista eroista, ikäihmisten osallisuudesta yhteiskunnassa, vanhuutta koskevista näkemyksistä sekä omaan vanhuuteen liittyvistä suunnitelmista.

Postikysely lähetettiin 5000:1le satunnaisesti valitulle 65-84-vuotiaalle suomalaiselle. Kyselyn vastausprosentti oli 62. Tutkimukseen osallistuvilla oli mahdollisuus vastata kyselyyn sähköisesti internetissä olleella lomakkeella tai postin kautta lähetetyllä perinteisellä kyselylomakkeella. Ensimmäiset kirjeet tutkittaville lähetettiin marraskuun lopussa 2020. Aineistonkeruu päättyi huhtikuussa 2021. Strukturoidun kyselylomakkeen teemoja olivat terveys ja toimintakyky, sosiaalinen verkosto ja aktiivisuus, ikääntyneiden asema yhteiskunnassa, palveluiden saatavuus ja muiden ihmisten auttaminen, tulevaisuutta koskevat ajatukset ja huolet, asuminen ja asuinympäristö sekä teknologian käyttö. Lisäksi lomakkeessa oli kysymyksiä ajankohtaisen koronapandemian vaikutuksista tutkittavien jokapäiväiseen elämään. Kyselylomakkeessa oli myös avovastauskysymyksiä, ja lomakkeen lopussa oli mahdollisuus kirjoittaa vapaamuotoisesti haluamastaan aiheesta. Vapaamuotoisia vastauksiakin tuli useita satoja, joten kyselyaineistosta 
on mahdollista tutkia laajasti ja monipuolisesti iäkkäiden ihmisten hyvinvointia.

\section{Tutkimukseen osallistuneiden taustatiedot}

Tutkimukseen osallistui 3081 henkilöä, joista 56 prosenttia oli naisia. Vastaajien keski-ikä oli 72 vuotta. Suurin osa (2195 henkilöä, 71 \%) vastasi perinteisellä, postin kautta tulleella paperilomakkeella. Yli kaksi kolmasosaa ilmoitti elävänsä parisuhteessa. Yksin asuminen oli selvästi yleisempää naisilla, joista 36 prosenttia asui yksin; miehistä vain 18 prosenttia ilmoitti asuvansa yksin. Kolmanneksella vastaajista oli perusasteen koulutus, ja vähintään opistoasteen koulutuksen oli saanut hieman yli kolmannes vastaajista. Miehistä 17 prosenttia ja naisista 8 prosenttia oli edelleen mukana työelämässä ainakin osa-aikaisesti. Terveydentilansa koki vähintään melko hyväksi 56 prosenttia vastaajista. Myös toimintakykynsä arvioi vähintään melko hyväksi yli puolet tutkittavista. Tarkemmat tutkimukseen osallistuneiden taustatiedot sukupuolittain on esitetty taulukossa 1 .

Taulukko 1. SoWell-postikyselyyn vastanneiden naisten ja miesten taustatiedot.

\begin{tabular}{lccc}
\hline Taustatiedot & $\begin{array}{c}\text { Naiset } \\
(\mathrm{n}=1729)\end{array}$ & $\begin{array}{c}\text { Miehet } \\
(\mathrm{n}=1351)\end{array}$ & $\begin{array}{c}\text { Yhteensä } \\
(\mathrm{n}=3 \text { 081) }\end{array}$ \\
\hline Ikä (keskiarvo, vuotta) & 72 & 72 & 72 \\
Parisuhteessa (\%) & 62 & 82 & 71 \\
Yksin asuminen (\%) & 36 & 18 & 28 \\
Koulutus (\%) & & 31 \\
$\quad$ Perusaste & 31 & 31 & 32 \\
$\quad$ Keskiaste & 32 & 37 \\
$\quad$ Vähintään opistoaste & 37 & 37 & 12 \\
Työelämässä ainakin osa-aikaisesti (\%) & 8 & 17 & 56 \\
Itsearvioitu terveys (\%) & & 53 & 33 \\
Vähintään melko hyvä & 57 & 35 & 11 \\
Keskiverto & 32 & 12 & 62 \\
Melko huono tai huono & 11 & & 28 \\
Itsearvioitu toimintakyky (\%) & & 59 & 10 \\
Vähintään melko hyvä & 64 & 30 & \\
Keskiverto & 26 & & \\
Melko huono tai huono & 10 & & \\
\hline
\end{tabular}

\section{Miten yli 65-vuotiaat suomalaiset voivat ja mikä heille on tärkeää?}

Suurin osa vastaajista oli tyytyväisiä (55 \%) tai hyvin tyytyväisiä (23 \%) nykyiseen elämäänsä. Elämään tyytyväisyydessä ei ollut eroa miesten ja naisten välillä. Yksinäisyyden kokemuksen suhteen vastaajat jakautuivat siten, että yli puolet ei tuntenut itseään koskaan yksinäiseksi, mutta 42 prosenttia tunsi olevansa joskus yksinäinen (taulukko 2). Yksinäisyyttä ei silti useinkaan koettu ongelmana. Yleisimpiä ak- tiviteetteja olivat ulkoliikunta, jonka mainitsi 79 prosenttia vastaajista, ystävien tapaaminen (73\%), luontoon liittyvät aktiviteetit, kuten sienestys, marjastus, kalastus ja metsästys (56 \%), sekä sisäliikuntaan osallistuminen (46\%).

Suurimpia huolenaiheita nyt tai tulevaisuudessa olivat naisilla lähiomaisen sairaus tai menettäminen, jonka mainitsi suureksi huolenaiheeksi 75 prosenttia naisista, oma terveys (63\%), avuttomuus tai riippuvuus ulkopuolisesta avusta $(53 \%)$ sekä eriarvoisuus maailmalla (43\%) ja Suomessa (41\%). Miehillä ylei- 
simmät huolenaiheet olivat naisten tapaan lähiomaisen sairaus tai menettäminen (68\%) ja oma terveys (52\%). Miehillä kolmanneksi yleisin huolenaihe oli eriarvoisuus maailmalla $(42 \%)$ ja seuraavana eriarvoisuus Suomessa (38\%).

Miltei kaksi kolmannesta (64\%) kyselyyn vastanneista ilmoitti olevansa täysin samaa mieltä siitä, että heillä on läheisiä ihmissuhteita, jotka antavat heille henkistä turvallisuuden tunnetta (taulukko 2). Osittain samaa mieltä edellä mainitun väittämän kanssa oli lähes kolmannes vastaajista. Vain kahdella prosentilla ei ollut lainkaan ihmissuhteita, joista he kokivat saavansa henkistä turvallisuuden tunnetta. Suurin osa vastaajista tiesi saavansa apua toisilta ihmisiltä silloin, kun sitä eniten tarvitsee. Avunsaannista täysin tai osittain epävarmoja oli vain 5 prosenttia. Tulokset viittaavat siihen, että läheisapu ja omaishoiva ovat osa monien iäkkäiden ihmisten arkea. Lähes puolet ilmoitti auttavansa säännöllisesti toimintakyvyltään heikentynyttä henkilöä. Usein autettava oli oma puoliso, jota kertoi auttavansa 37 prosenttia naisista ja 46 prosenttia miehistä. Toisen ihmisen auttamisen koettiin antavan itselle paljon (66 \% vastaajista), mutta toisaalta auttaminen tuntui raskaalta ja stressaavalta lähes joka kolmannelle auttajalle. Kyselyn tulokset viittaavat siihen, että ikääntyneet ihmiset eivät täysin luota suomalaiseen palvelujärjestelmään. Vastaajista 78 prosenttia luotti siihen, että Suomessa saa kiireellistä hoitoa vakavaan sairauteen, mutta vain 39 prosenttia luotti siihen, että ikääntyneet ihmiset saavat Suomessa kotiin tuotavia hoito- ja hoivapalveluja (esim. kotihoito, ateria- ja muut tukipalvelut, kuntoutuspalvelut ja kodinmuutostyöt), ja vain 21 prosenttia luotti ympärivuorokautisen hoidon saamiseen. Luottamuksessa palvelujärjestelmään ei ollut eroja naisten ja miesten välillä.

Julkisissa keskusteluissa puhutaan paljon digitalisaatiosta ja siitä, miten digitalisoituminen voi syrjäyttää iäkkäitä ihmisiä yhteiskunnan toiminnasta ja aiheuttaa ongelmia päivittäisten asioiden hoidossa. Tämän kyselyn tu- losten mukaan suurin osa ikääntyvistä on hyvin kiinni älyteknologian kehityksessä ja käyttää säännöllisesti erilaisia digitaalisia palveluita ja sosiaalisen median välineitä. Naisista 63 prosenttia ja miehistä 70 prosenttia käytti internetiä päivittäin, ja viikoittain sitä käytti 15 prosenttia naisista ja 10 prosenttia miehistä. Internetiä ei ollut koskaan käyttänyt 15 prosenttia naisista ja 14 prosenttia miehistä. Vastaajista 73 prosenttia kertoi, että heillä oli käytössä älypuhelin, ja 81 prosenttia käytti tietokonetta tai tablettitietokonetta. Valtaosa (88 \%) ilmoitti teknologian käytön helpottavan asiointia, eikä naisten ja miesten välillä ollut eroa vastauksissa. Kiinnostava tulos oli se, että teknologian yleisestä käytöstä huolimatta 71 prosenttia asioisi mieluummin kasvotusten tai puhelimitse.

\section{Koronapandemian vaikutukset yli 65-vuotiaiden suomalaisten elämään}

Korona-ajan rajoituksista ja yli 70-vuotiaisiin kohdistuneiden rajoitusten hyväksyttävyydestä on keskusteltu paljon. Tämän kyselyn vastaajista enemmistö (85 \%) oli sitä mieltä, että yli 70-vuotiaille kohdennetut kehotukset välttää sosiaalista kanssakäymistä olivat olleet asiallisia. Korona-ajalla näytti olleen vaikutuksia arjen toimintoihin, mutta ei kovin suurta vaikutusta hyvinvoinnin kokemukseen. Pandemian aikana liikkuminen kodin ulkopuolella oli vähentynyt 79 prosentilla ja kasvokkainen kanssakäyminen toisten ihmisten kanssa 90 prosentilla vastaajista. Yhteydenpito toisiin ihmisiin puhelimen tai älylaitteiden avulla puolestaan oli lisääntynyt 80 prosentilla. Kun kysyttiin "oletko ollut koronan vaikutuksista niin huolissasi, että se on vaikuttanut omaan hyvinvointiisi", täysin samaa mieltä oli vain 4 prosenttia naisista ja 3 prosenttia miehistä ja täysin eri mieltä 47 prosenttia naisista ja 54 prosenttia miehistä. Vastaajat olivatkin enemmän huolissaan läheistensä hyvinvoinnista (77 \%) ja siitä, miten koko maailma selviää (83 \%) pandemiasta. 
Taulukko 2. Yksinäisyys, läheiset ihmissuhteet ja auttaminen.

\begin{tabular}{|c|c|c|c|}
\hline Muuttujat (\%) & $\begin{array}{c}\text { Naiset } \\
(n=1729)\end{array}$ & $\begin{array}{c}\text { Miehet } \\
(n=1351)\end{array}$ & $\begin{array}{l}\text { Yhteensä } \\
(n=3081)\end{array}$ \\
\hline \multicolumn{4}{|l|}{ Tunnen yksinäisyyttä } \\
\hline Usein & 4 & 4 & 4 \\
\hline Joskus & 48 & 35 & 42 \\
\hline En koskaan & 48 & 61 & 54 \\
\hline \multicolumn{4}{|l|}{ Yksinäisyys on ongelma } \\
\hline Usein & 1 & 1 & 1 \\
\hline Joskus & 25 & 20 & 23 \\
\hline Ei koskaan & 74 & 79 & 76 \\
\hline \multicolumn{4}{|l|}{ Minulla on henkistä turvaa antavia ihmissuhteita } \\
\hline Täysin samaa mieltä & 70 & 56 & 64 \\
\hline Osittain samaa mieltä & 24 & 35 & 29 \\
\hline Osittain eri mieltä & 4 & 6 & 5 \\
\hline Täysin eri mieltä & 2 & 3 & 2 \\
\hline \multicolumn{4}{|l|}{ Saan tarvittaessa apua toisilta ihmisiltä } \\
\hline Täysin samaa mieltä & 71 & 62 & 67 \\
\hline Osittain samaa mieltä & 25 & 32 & 28 \\
\hline Osittain eri mieltä & 3 & 5 & 4 \\
\hline Täysin eri mieltä & 1 & 1 & 1 \\
\hline \multicolumn{4}{|l|}{ Autan säännöllisesti } \\
\hline Puolisoa & 37 & 46 & 41 \\
\hline Lasta/lapsenlasta & 24 & 17 & 21 \\
\hline Ystävää/tuttavaa & 22 & 20 & 21 \\
\hline läkästä sukulaista & 21 & 19 & 20 \\
\hline Naapuria & 15 & 17 & 16 \\
\hline \multicolumn{4}{|l|}{ Miltä auttaminen tuntuu } \\
\hline Antaa itselle paljon & 62 & 70 & 66 \\
\hline Tuntuu raskaalta tai stressaavalta & 37 & 20 & 29 \\
\hline Aiheuttaa jatkuvaa huolta & 20 & 12 & 16 \\
\hline En auttaisi, jos olisi toinen vaihtoehto & 4 & 2 & 3 \\
\hline
\end{tabular}

\section{Pohdintaa prosessista ja tulevasta}

Yhteenvetona kyselyn tuloksista voi sanoa, että vastanneiden 65-84-vuotiaiden suomalaisten terveys ja elämäntilanne näyttävät yleisesti ottaen varsin hyvältä. Tapa, jolla iäkkäistä ihmisistä julkisuudessa puhutaan, on negatiivisesti sävyttynyt ja keskittyy hyvin paljon terveysongelmiin. Kyselyn alustavat tulokset antavat aihetta kysyä, kuinka oikea tämä kuva on. Varauksena edelliseen on kuitenkin todettava, että kyselyyn vastaamatta jättäneiden 40 prosentin joukossa on todennäköisesti niitä, joiden terveys ja toimintakyky on huonompi kuin vastaajajoukolla. Kyselyn vastausprosentti (62 \%) on joka tapauksessa varsin hyvä. Iäkkäät ihmiset vastaavat yleensäkin kyselyihin paremmin kuin nuoremmat, mutta merkitystä oli todennäköisesti myös sillä, että ensimmäisen sähköisen kyselykutsun jälkeen postitettiin myös paperinen lomake. Toisenkaan kutsun jälkeen ei luovutettu, vaan ei-vastanneille lähetettiin vielä yksi kutsu, mikä nostikin hieman vastausprosenttia.

Yksi tärkeä havainto kyselyaineiston keruusta oli se, että päätös antaa vastaajille mahdollisuus vastata joko sähköisesti tai paperisella kyselylomakkeella osoittautui oikeaksi. Suurin osa (71\%) vastasi perinteisellä, postin kautta tulleella paperilomakkeella, ja sähköisesti vas- 
tanneita oli noin kolmannes. Syynä paperilla vastaamisen painottumiseen voi olla se, ettei sähköinen vastaamismahdollisuus onnistunut tavoittamaan kyllin laajasti tämän ikäisiä, tai se, että paperinen kotiin tuleva valmiilla vastauskuorella varustettu kysely koetaan edelleen helpommaksi vastaustavaksi. Tulos antaa joka tapauksessa vertailukohtaa muille sähköisesti toteutettaville kyselyille ja tutkimuksille sekä aihetta pohtia, kuinka hyvin pelkät sähköiset aineistonkeruut tavoittavat iäkkäitä ihmisiä ja mikä on niiden edustavuus.

Valmistunut kyselyaineisto tarjoaa aineistoa ikääntyvien ihmisten sosiaalisen hyvinvoinnin ja yhteiskunnallisen osallisuuden tarkasteluun monesta eri näkökulmasta. Tulokset läheisiään auttavien suuresta määrästä antavat vertailukohtaa pohtia iäkkäiden ihmisten asemaa ja panosta yhteiskunnassa. Toisaalta alustavat tulokset osoittavat melko suurta epäluottamusta vanhuspalveluiden saamista kohtaan, mikä johtaa pohtimaan, ovatko laajasti tiedossa olevat vanhuspalveluiden ongelmat jo vahingoittaneet ikääntyvien ihmisten yhteiskuntaa kohtaan tuntemaa luottamusta. Valmisteilla olevissa tutkimuksissa tarkastellaan muun muassa kokemuksia koronapandemiasta, asuinympäristön, palveluiden ja hyvinvoinnin välisiä yhteyksiä sekä sitä, millaista teknologiaa ikääntyneillä on käytössään ja miten he kokevat teknologian tuomat muutokset arjessaan ja sosiaalisissa suhteissaan. SoWell-hankkeen yhtenä keskeisenä tavoitteena on tuoda suomalaiseen keskusteluun lisää tietoa iäkkäiden ihmisten moninaisuudesta, erilaisista elämäntilanteista ja tavoista toimia omissa lähiyhteisöissään ja yhteiskunnassa. Tuloksia raportoidaankin jatkossa myös suomeksi ja erilaisissa yleisötilaisuuksissa.

Kristina Tiainen, $\mathrm{Tt} \mathrm{T}$, dosentti, yliopistotutkija

Tampereen yliopisto

Kirsi Nousiainen, TtM

Tampereen yliopisto

Katariina Tuominen, TtM, väitöskirjatutkija

Tampereen yliopisto

Päivi Ahosola, TtM, FT, tutkijatohtori

Tampereen yliopisto

Marja Jylhä, LT, professori

Tampereen yliopisto

Outi Jolanki, FT, dosentti

Tampereen yliopisto ja Jyväskylän yliopisto

\section{Kirjallisuus}

Ahosola P, Tuominen K, Tiainen K, Jylhä M, Jolanki O. Mikä muuttui vai muuttuiko mikään? Yli 65-vuotiaiden arki korona-aikana. Gerontologia 2021. https://doi.org/10.23989/gerontologia.103376

Pirhonen J, Jolanki O, Tuominen K, Jylhä M. Hyvän elämän edellytyksiä etsimässä - SoWell-tutkimushanke keskittyy sosiaaliseen hyvinvointiin ja sen parantamiseen. Gerontologia 2018; 32(4):292-5. https://doi.org/10.23989/gerontologia.77882 